\title{
Pregnancy, Bovine Somatotropin, and Dietary n-3 Fatty Acids in Lactating Dairy Cows: I. Ovarian, Conceptus, and Growth Hormone-Insulin-Like Growth Factor System Responses
}

\author{
T. R. Bilby, A. Sozzi, M. M. Lopez, F. T. Silvestre, A. D. Ealy, C. R. Staples, and W. W. Thatcher ${ }^{1}$ \\ Department of Animal Sciences, University of Florida, Gainesville 32611
}

\begin{abstract}
The objective was to examine effects of bovine somatotropin (bST), pregnancy, and dietary fatty acids on reproductive responses in lactating dairy cows. Beginning at approximately $17 \mathrm{~d}$ in milk (DIM), a comparison was made of isoenergetic diets comprising supplementary lipids of whole cottonseed vs. calcium salts of fish oil enriched lipid (FO). Ovulation was synchronized in cows with a presynchronization plus Ovsynch protocol, and cows were inseminated artificially by appointment or not inseminated ( $0=$ time of synchronized ovulation; $77 \pm 12 \mathrm{DIM}$ ). On $\mathrm{d} 0$ and 11 , cows received bST (500 mg) or no bST. All cows were slaughtered on d 17. Number of cows in each group was as follows: control diet had 5 bST-treated cyclic (bST-C), 5 non-bSTtreated cyclic (no bST-C), 4 bST-treated pregnant (bST$\mathrm{P}$ ), and 5 non-bST-treated pregnant (no bST-P) cows; and cyclic cows fed FO diet had 4 bST-treated (bSTFO) and 5 non-bST-treated cyclic (no bST-FO-C) cows. Feeding FO increased milk production, number of class 1 follicles (2 to $5 \mathrm{~mm}$ ), and decreased insulin during the period before d 0 compared with control-fed cows. The bST increased milk production, pregnancy rate [83\% (5/6) vs. $40 \%(4 / 10)]$, conceptus length (45 vs. 34 $\mathrm{cm}$ ), and interferon- $\tau$ in the uterine luminal flushings $(9.4$ vs. $5.3 \mu \mathrm{g})$ with no effect on interferon- $\tau$ mRNA concentration in the conceptus. Treatment with bST increased plasma growth hormone $(\mathrm{GH})$ and insulinlike growth factor (IGF)-I. Among control-fed cows (cyclic and pregnant), bST decreased progesterone concentration in plasma. Cows fed FO had less plasma insulin than control-fed cyclic cows, and FO altered the plasma GH (bST-FO > bST-C) and IGF-I (bST-C > bST-FO-C) responses to bST injections. Endometrial IGF-I mRNA was reduced in pregnant cows and tended to decrease in those fed FO. The IGF-II mRNA was increased in the endometrium of pregnant and bST-treated cows fed the control diet. Cows fed FO had increased concentra-
\end{abstract}

Received October 21, 2005.

Accepted April 5, 2006.

${ }^{1}$ Corresponding author: thatcher@animal.ufl.edu tions of IGF-II mRNA, when bST was not injected. The insulin-like growth factor binding protein-2 (IGFBP2) mRNA was increased in bST-P cows, whereas bST decreased the IGFBP-2 mRNA in all cyclic cows. In summary, bST and FO seemed to modulate reproductive responses that may be beneficial to the developing conceptus and pregnancy rate.

Key words: pregnancy, bovine somatotropin, fish oil

\section{INTRODUCTION}

Exogenous injections of bST improve lactational performance, increasing milk production by an average of 3 to $5 \mathrm{~kg} / \mathrm{d}$ (Bauman et al., 1999). When lactating dairy cows were injected with bST (500 mg) at either the initiation of the Ovsynch program or at the time of AI, lactating dairy cows that were cycling had greater pregnancy rates than controls $(53.2,44.9$, and $38.8 \%$, respectively; Moreira et al., 2001). An additional study documented the beneficial effect of bST on pregnancy rates when injected during the period approaching AI (Santos et al., 2004).

Beneficial effects of bST on fertilization and embryonic development both in vitro and in vivo of lactating dairy cows are associated with the rise in circulating concentrations of growth hormone (GH) and IGF-I (Moreira et al., 2002a,b). Pershing et al. (2002) examined the effects of bST, given at the time of AI during the Ovsynch protocol, on expression of oviductal and uterine genes encoding components of the IGF system on $\mathrm{d} 3$ and 7 following a synchronized ovulation. This study revealed the regulatory complexity of bST on tissue-specific gene expression of the IGF system during early pregnancy in lactating dairy cows.

Little is known of the effects of bST after $d 7$ and before $\mathrm{d} 32$ post-AI, which appears to be a critical period for bST to exert direct embryonic or indirect effects via the uterus and (or) circulating hormones such as IGFI (Moreira et al., 2001). Another important event within this critical window, on d 16 to 17 after estrus, is maintenance of the corpus luteum (CL). This process is established by the ability of the conceptus to secrete IFN$\tau$, which regulates secretion of $\mathrm{PGF}_{2 \alpha}$ by the uterine 
endometrium (Thatcher et al., 2001). It is estimated that at least $40 \%$ of total embryonic losses occur between $\mathrm{d} 8$ and 17 of pregnancy. This high proportion of embryonic losses seems to occur about the same time that the conceptus inhibits pulsatile $\mathrm{PGF}_{2 \alpha}$ secretion. Because supplemental bST increases the rate of embryo development to the blastocyst stage and cell numbers in vitro and in vivo (Moreira et al., 2002a,b), bST may subsequently enhance conceptus development by allowing for a greater secretion of IFN- $\tau$ at $d 17$ of pregnancy. An increase of IFN- $\tau$ may contribute to an increase in the number of cows establishing pregnancy and a decrease in those having early embryonic loss.

An additional strategy to potentially increase embryo survival is the addition of fish oil (FO) to the diet (Mattos et al., 2000). Production of $\mathrm{PGF}_{2 \alpha}$ was also reduced by bovine endometrial cells incubated with eicosapentaenoic acid (EPA; C20:5) and docosahexaenoic acid (DHA; C22:6; Mattos et al., 2003). Thus, EPA and DHA may contribute to the antiluteolytic effect of early pregnancy and increase embryo survival. Few studies have investigated, however, the effects of long-chain fatty acids, bST, and their interaction on the uterine environment.

The objective of this study was to characterize the effects of exogenous bST, dietary fatty acids enriched in $\mathrm{FO}$, and pregnancy on ovarian function, conceptus development, and regulation of the GH-IGF system in the uterus on and before $d 17$ of the estrous cycle in lactating Holstein cows.

\section{MATERIALS AND METHODS}

\section{Materials}

Gonadotropin-releasing hormone (Fertagyl; Intervet Inc., Millsboro, DE), $\mathrm{PGF}_{2 \alpha}$ (Lutalyse; Pfizer Animal Health, Kalamazoo, MI), and bST (Posilac; Monsanto Co., St. Louis, MO) were used for synchronization of ovulation and experimental treatment. Recombinant bovine IFN- $\tau\left(1.08 \times 10^{7}\right.$ IU of antiviral activity per mg used as a standard) for the antiviral assay was a generous gift from Michael Roberts (University of Missouri, Columbia, MO). The cDNA of growth hormone receptor-1A (GHR-1A), IGF-I, IGF-II, insulinlike growth factor binding protein (IGFBP)-2, and IGFBP-3 were a generous gift from Mathew Lucy (University of Missouri, Columbia, MO). All other materials were purchased: Trizol, Random Primers DNA Labeling System (Invitrogen Corporation, Carlsbad, CA), Taq polymerase (M166A; Promega, Madison, WI), ultrasensitive hybridization buffer (ULTRAhyb; Ambion Inc., Austin, TX), dCTP $\alpha{ }^{3}{ }^{32} \mathrm{P}$ (MP Biomedicals, Irvine, CA), Biotrans nylon membrane (MP Biomedicals, Irvine, CA), RNAqueous-4 PCR kit and RNase-free DNase
(Ambion Inc.), real-time PCR probes (Biosearch Technologies, Novato, CA), TAQ Gold polymerase, Moloney murine leukemia virus reverse transcriptase, and $18 \mathrm{~S}$ RNA control reagent (Applied Biosystems; Foster City, CA), Centriprep Centrifugal Filter Devices (Millipore, Bedford, MA), nitrocellulose membranes (Hybond, Amersham Biosciences Corp., Piscataway, NJ), recombinant human IGF-I and IGF-II (Upstate Biotechnology, Lake Placid, NY), Modified Eagle's medium, and immortalized Madin-Darby bovine kidney cells were purchased from American Type Culture Collection (Manassas, VA). All other general materials used were from Fisher Scientific (Pittsburgh, PA) and Sigma Chemical Co. (St. Louis, MO).

\section{Cows and Experimental Diets}

The experiment was conducted at the University of Florida Dairy Research Unit (Hague, FL) from October 2002 through February 2003. Cows were managed according to the guidelines approved by the University of Florida Animal Care and Use Committee. Forty multiparous Holstein cows in late gestation were housed in sod-based pens and fed diets formulated to contain 1.51 Mcal of $\mathrm{NE}_{\mathrm{L}} / \mathrm{kg}, 13.1 \% \mathrm{CP}$, and a cation-anion difference of $-90 \mathrm{mEq} / \mathrm{kg}$ (DM basis) beginning approximately 3 wk before expected calving. Upon calving, cows were moved to a freestall facility having grooved concrete floors, and fans and sprinklers that operated when the temperature exceeded $25^{\circ} \mathrm{C}$. Cows were offered ad libitum amounts of a TMR to allow 5 to $10 \%$ feed refusals daily. Two dietary treatments were fed containing none or $1.9 \%$ calcium salt of a fish oil-enriched lipid (FO) product (EnerG-II Reproduction formula, Virtus Nutrition, Fairlawn, $\mathrm{OH})$. The fatty acid profile of the fat source as given by the manufacturer was $2.2 \% \mathrm{C} 14: 0$, $41 \% \mathrm{C} 16: 0,4.2 \% \mathrm{C} 18: 0,30.9 \% \mathrm{C} 18: 1,0.2 \% \mathrm{C} 18: 1$ trans, 8.0\% C18:2, 0.5\% C18:3, 0.4\% C20:4, 2.0\% C20:5, 2.3\% $\mathrm{C} 22: 6$, and $2.7 \%$ unknown. The control diet contained a greater concentration of whole cottonseed, but was similar in concentration of ether extract and $\mathrm{NE}_{\mathrm{L}}$ (Table 1) to that containing FO. The control diet was fed to all cows during the first 9 DIM. Thirty cows were assigned to the control diet for the duration of the study. From 10 to 16 DIM, 10 cows were assigned to consume a FO diet containing half the final concentration of the fat product $(0.95 \%$ of dietary DM) to adjust the cows to a new fat source. Starting at 17 DIM, these cows were switched to the $1.9 \% \mathrm{FO}$ diet and continued on that diet until the end of the study. Cows fed the ruminally protected FO consumed approximately $14.8 \mathrm{~g} / \mathrm{cow}$ per day of EPA and DHA. Dry matter of corn silage was determined weekly $\left(55^{\circ} \mathrm{C}\right.$ for $48 \mathrm{~h}$ ), and diets were adjusted accordingly to maintain a constant forage:con- 
Table 1. Ingredient and chemical composition of diets containing none or $1.9 \%$ calcium salts of fish oil-enriched lipid product (FO)

\begin{tabular}{lcc}
\hline & $0 \%$ & $1.9 \%$ \\
Composition & FO & FO \\
\hline Ingredients, \% of DM & & \\
Corn silage & 30.2 & 30.2 \\
Alfalfa hay & 7.5 & 12.0 \\
Cottonseed hulls & 4.9 & 4.9 \\
Citrus pulp & & 5.2 \\
Soy plus & 6.3 & 5.8 \\
Corn meal & 23.9 & 18.5 \\
Soybean meal & 7.6 & 11.0 \\
Whole cottonseeds & 14.8 & 5.8 \\
Mineral and vitamin mix & 4.8 & 4.8 \\
Ca salt of FO & - & 1.9 \\
Chemical composition & & \\
NE, 3 Mcal/kg of DM & 1.66 & 1.68 \\
CP, \% of DM & 16.8 & 10.9 \\
CP-RDP, \% of DM & 10.7 & 6.2 \\
CP-RUP, \% of DM & 6.1 & 21.4 \\
ADF, \% of DM & 22.6 & 31.2 \\
NDF, \% of DM & 33.7 & 4.7 \\
Lignin, \% of DM & 5.4 & 5.2 \\
Ether extract, \% of DM & 6.0 & 35.8 \\
NFC, \% of DM & 34.4 & 10.7 \\
Ash,\% of DM & 9.1 & 1.9 \\
Ca, \% of DM & 1.29 & 0.38 \\
P, \% of DM & 0.41 & 0.5 \\
Mg, \% of DM & 0.53 & 1.45 \\
K, \% of DM & 1.34 & 0.98 \\
Na, \% of DM & 0.93 & 0.3 \\
S, \% of DM & 0.26 & 131 \\
Fe, mg/kg of DM & 109 & \\
Zn, mg/kg of DM & 56 & \\
Cu, mg/kg of DM & 103 & \\
Mn, mg/kg of DM & & \\
\hline & & \\
& &
\end{tabular}

${ }^{1}$ Mineral mix contained $26.4 \% \mathrm{CP} ; 1.74 \%$ fat; $10.15 \% \mathrm{Ca} ; 0.90 \% \mathrm{P}$; $3.1 \% \mathrm{Mg} ; 8.6 \% \mathrm{Na} ; 5.1 \% \mathrm{~K} ; 1.5 \% \mathrm{~S} ; 4.1 \% \mathrm{Cl} ; 2,231 \mathrm{mg} / \mathrm{kg}$ of $\mathrm{Mn}$; $1,698 \mathrm{mg} / \mathrm{kg}$ of $\mathrm{Zn} ; 339 \mathrm{mg} / \mathrm{kg}$ of Fe; $512 \mathrm{mg} / \mathrm{kg}$ of Cu; $31 \mathrm{mg} / \mathrm{kg}$ of Co; $26 \mathrm{mg} / \mathrm{kg}$ of I; $7.9 \mathrm{mg} / \mathrm{kg}$ of Se; $67,021 \mathrm{IU} / \mathrm{kg}$ of vitamin A; 19,845 $\mathrm{IU} / \mathrm{kg}$ of vitamin D; and $357 \mathrm{IU} / \mathrm{kg}$ of vitamin E (DM basis).

${ }^{2}$ EnerG II Reproduction Formula, Virtus Nutrition, Fairlawn, OH.

${ }^{3}$ Calculated using $\mathrm{NE}_{\mathrm{L}}$ values published by NRC (2001).

${ }^{4}$ Calculated using RUP values for individual feedstuffs as given by NRC (2001)

${ }^{5}$ Calculated as $(\% \mathrm{NFC}=100 \%-\% \mathrm{CP}-\% \mathrm{NDF}-\%$ fat $-\%$ ash $)$.

centrate ratio on a DM basis. Samples of forages and concentrate mixes were collected weekly, composited monthly, and analyzed by wet chemistry methods for chemical composition (Dairy One, Ithaca, NY; Table 1). Cows were milked thrice daily and milk weights were recorded by calibrated electronic milk meters at each milking. Body weights were measured and BCS (Wildman et al., 1982) assigned weekly by the same 2 individuals.

\section{Estrus Synchronization, Ultrasonography of Ovaries, and bST Treatment}

Estrus was presynchronized starting at $44 \pm 5$ DIM [d -27 in relation to day of timed AI (TAI)] using an injection of GnRH ( $86 \mu \mathrm{g}$; i.m.) followed $7 \mathrm{~d}$ later with an injection of $\mathrm{PGF}_{2 \alpha}(25 \mathrm{mg}$; i.m.) on $\mathrm{d}-20$. Standing activity was estimated during the next $10 \mathrm{~d}$ by using the Heatwatch electronic estrus-detection system (DDx Inc., Denver, CO). At the end of $10 \mathrm{~d}$, the TAI protocol was initiated using a $\mathrm{GnRH}$ injection (86 $\mu \mathrm{g}$; i.m.) followed $7 \mathrm{~d}$ later by an injection of $\mathrm{PGF}_{2 \alpha}(25 \mathrm{mg}$; i.m.). At $48 \mathrm{~h}$ after injection of $\mathrm{PGF}_{2 \alpha}$, GnRH (86 $\mu$ g; i.m.) was administered, and 16 cows fed the control diet were inseminated $16 \mathrm{~h}$ later. All inseminations were administered by the same technician with semen from $1 \mathrm{Hol}-$ stein bull (7H05379) of known fertility (Select Sires, Plain City, OH). The cycling group $(\mathrm{n}=19)$ was not inseminated. Inseminated and noninseminated cows received either an injection of bST (500 mg) or no injection on $\mathrm{d} 0$ (when cows were either inseminated or not) and again on $\mathrm{d} 11$. The bST injections were given $11 \mathrm{~d}$ apart instead of $14 \mathrm{~d}$, to allow for a sustained continual exposure to $\mathrm{GH}$ until d 17 at which time cows were slaughtered. The bST injections were given s.c. in the space between the ischium and tail head. Ovaries of both inseminated and noninseminated cows were evaluated by real-time ultrasonography (Aloka SSD-500, Aloka Co., Ltd., Tokyo, Japan) using a 7.5-MHz lineararray transrectal transducer on d $0,7,9,11,13,15,16$, and 17. The following follicular responses were assessed: numbers of class 1 ( 2 to $5 \mathrm{~mm}$ ), class 2 (6 to 9 $\mathrm{mm})$, and class $3(\geq 10 \mathrm{~mm})$ follicles, number of CL, diameter of the largest follicle ( $\mathrm{mm})$, and volume of CL tissue $\left(\mathrm{mm}^{3}\right)$. Volume of CL tissue was calculated using the following equation: volume $=1.333 \times \pi \times$ radius $^{3}$, where radius $=($ length $/ 2+$ width $/ 2) / 2$. For CL with a fluid-filled cavity, the volume of the cavity was calculated and subtracted from the total volume of the CL. Three cows were excluded for various health concerns and CL regression before $\mathrm{d} 17$ was observed in 2 cows. These 5 cows were excluded from the study. Cows ( $\mathrm{n}=$ 35) were slaughtered on d 17 after TAI to collect tissue samples and verify presence of a conceptus. Pregnancy rates were defined as number of cows classified pregnant based upon visualization of a conceptus in the uterine flushing at slaughter divided by number of cows inseminated. From the inseminated cows that were slaughtered, 6 cows not treated with bST and 1 cow treated with bST were not pregnant. These 7 cows were not used for any analyses from d 0 to 17 following TAI. Number of cows used for analyses from d 0 to 17 for the control diet: 5 bST-treated cyclic (bST-C), 5 nonbST-treated cyclic (no bST-C), 4 bST-treated pregnant (bST-P), and 5 non-bST-treated pregnant (no bST-P) cows; and cyclic cows for the FO diet: 4 bST-treated FO-cyclic (bST-FO-C) and 5 non-bST-treated cyclic (no bST-FO-C) cows. 
Table 2. Bovine IFN- $\tau$ primers and probe sequences used for quantitative real-time reverse transcription-PCR

\begin{tabular}{ll}
\hline Primer/probe $^{1}$ & Sequence $\left(5^{\prime}\right.$ to $\left.3^{\prime}\right)$ \\
\hline IFN- $\tau$ SE & TGCAGGACAGAAAAGACTTTGGT \\
IFN $\tau$ AS & CCTGATCCTTCTGGAGCTGG \\
IFN- $\tau$ probe & TTCCTCAGGAGATGGTGGAGGGCA \\
\hline
\end{tabular}

${ }^{1} \mathrm{SE}=$ sense primer $\left(5^{\prime}\right.$ primer $) ; \mathrm{AS}=$ antisense primer $\left(3^{\prime}\right.$ primer $)$; probe was synthesized with a FAM reporter dye and $\mathrm{BHQ}-1$ quencher.

\section{Tissue Sample Collection}

All cows were slaughtered in the abattoir of the Animal Sciences Department at the University of Florida. Reproductive tracts were collected within $10 \mathrm{~min}$ of slaughter, placed on ice, and taken to the laboratory. Conceptuses and uterine secretions were recovered as described by Bilby et al. (2004). Endometrial tissue and CL were collected as described by Bilby et al. (2004). Endometrial tissues and uterine luminal flushings (ULF) were collected from 11 cycling ( 5 no bST-C and 6 bST-C) cows fed the control diet, 8 cycling cows fed a FO diet (4 no bST-FO-C and 4 bST-FO-C), and 9 pregnant (4 no bST-P and 5 bST-P) cows fed the control diet.

\section{IFN- $\tau$ Antiviral Assay}

Activity is expressed in terms of antiviral units per milliliter as assessed in a standard cytopathic effect assay (Bilby et al., 2004).

\section{Quantitative Real-Time Reverse Transcription-PCR}

Quantitative real-time reverse transcription-PCR was used to measure the relative abundance of IFN- $\tau$ mRNA in conceptuses. Total cellular RNA was extracted from conceptuses with the RNAqueous-4 PCR kit. All samples were incubated with RNase-free DNase at the end of RNA extraction and again immediately before reverse transcription. Total cellular RNA (20 ng) was reverse-transcribed using Moloney murine leukemia virus reverse transcription. Reactions that were not exposed to reverse transcription were included on a subset of samples to verify that samples were free of genomic DNA contamination. Specific primers and probe sets were used for amplifying reverse transcription product from conceptus samples (Table 2). The IFN- $\tau$ primers and probe were developed to recognize every known bovine and ovine IFN- $\tau$ isoform. The IFN$\tau$ probes were labeled with a fluorescent $5^{\prime}$ reporter dye (FAM) and 3' quencher (BHQ-1). Forty-five cycles of PCR were completed using TAQ Gold polymerase and the ABI PRISM 7700 Sequence Detection System. Abundance of 18S RNA was used as a loading control by adding $18 \mathrm{~S}$ primers and an $18 \mathrm{~S}$ probe containing a VIC-labeled $5^{\prime}$ fluorescent reporter and $3^{\prime}$ TAMRA quencher within the real-time PCR reactions. Each RNA sample was analyzed in triplicate reactions.

Comparative threshold cycle $\left(\mathbf{C}_{\mathbf{T}}\right)$ method was used to quantify the abundance of bovine IFN- $\tau$ mRNA relative to that of 18S RNA (ABI Prism Sequence Detection System User Bulletin No. 2; Applied Biosystems). The $\mathrm{C}_{\mathrm{T}}$ number for FAM (IFN- $\tau$ mRNA) and VIC (18S RNA) fluorescence was calculated within the geometric region of the plot generated during PCR. The $\Delta \mathrm{C}_{\mathrm{T}}$ value was determined by subtracting the $18 \mathrm{~S} \mathrm{C}_{\mathrm{T}}$ value from the bovine IFN- $\tau \mathrm{C}_{\mathrm{T}}$ value of the same sample. The $\Delta \Delta \mathrm{C}_{\mathrm{T}}$ for each sample was calculated by subtracting the highest sample $\Delta \mathrm{C}_{\mathrm{T}}$ value (i.e., the sample with the lowest target expression) from the remaining values. Because each unit of $\Delta \Delta \mathrm{C}_{\mathrm{T}}$ difference is equivalent to a doubling in the amplified PCR product, fold changes in relative bovine IFN- $\tau$ mRNA abundance were determined by solving for $2^{-\Delta \Delta \mathrm{CT}}$.

\section{RNA Isolation and Northern Blotting}

Total RNA was isolated from endometrial tissues (300 mg of fresh weight; $\mathrm{n}=28$ ) and Northern blotting procedure was performed as described by Bilby et al. (2004). Specific bovine cDNA used were GHR-1A, IGFI, IGF-II, IGFBP-2, IGFBP-3, and glyceraldehyde-3phosphate dehydrogenase.

\section{Analysis of Hormones in Plasma and ULF}

Blood samples $(7 \mathrm{~mL})$ were collected just after the afternoon feeding $(1300 \mathrm{~h})$ twice weekly from 14 until $44 \pm 5$ DIM and daily from TAI (d 0; $77 \pm 12$ DIM) until slaughter (d 17; $94 \pm 12$ DIM) from a coccygeal blood vessel in 3 different locations, which were rotated at each bleeding to minimize irritation. Vacutainer blood collection needles (20-G; Becton Dickinson and Co. Franklin Lakes, NJ) were used. Samples were collected in evacuated heparinized tubes (Vacutainer; Becton Dickinson, East Rutherford, NJ). Immediately following sample collection, blood was stored on ice until it was returned to the laboratory for centrifugation $(3,000$ $\times g$ for 20 min at $4^{\circ} \mathrm{C}$ ) for collection of plasma within 6 h. Plasma was stored at $-20^{\circ} \mathrm{C}$ until assayed for $\mathrm{GH}$, IGF-I, insulin, and progesterone. Concentrations of progesterone were analyzed using a solid-phase radioimmunoassay (RIA) kit (Coat-A-Count Progesterone, Diagnostic Products Co., Los Angeles, CA) validated in our laboratory (Garbarino et al., 2004). Plasma samples were analyzed for GH (Badinga et al., 1991), insulin (Badinga et al., 1991), and IGF-I (Badinga et al., 1991) by specific RIA. The extraction procedure used for the 
IGF-I assay (Badinga et al., 1991) was modified slightly using a 6:3:1 ratio of ethanol:acetone:acetic acid. The ULF were concentrated with a Centriprep Centrifugal Filter Device fitted with a 3000-MW filter and then analyzed for IGF-I and GH using the same RIA procedures. Values for immunoreactive IGF-I and GH were expressed as total nanograms in ULF. Protein concentrations in ULF were determined as described by Bilby et al. (2004). The minimum detectable concentrations for GH, IGF-I, insulin, and progesterone were $0.1,10$, 0.02 , and $0.1 \mathrm{ng} / \mathrm{mL}$, respectively. The intra- and interassay coefficients of variation for plasma progesterone, GH, IGF-I, and insulin were 7.7 and 6.0\%, 9.1 and $4.9 \%, 7.0$ and $4.9 \%$, and 4.8 and $7.8 \%$, respectively. Plasma concentrations of progesterone had intraassay coefficients of variation calculated from duplicated samples in 3 ranges of low $(0.5$ to $1 \mathrm{ng} / \mathrm{mL} ; 6.8 \%)$, medium ( 1 to $3 \mathrm{ng} / \mathrm{mL} ; 7.4 \%$ ), and high ( $>3 \mathrm{ng} / \mathrm{mL} ; 4.3 \%$ ) progesterone concentrations. A reference pool for ULF resulted in intraassay coefficients of variation of 5.3 and $8.3 \%$ for GH and IGF-I, respectively. The intraassay coefficients of variation for duplicate concentrated samples within the complete assay for the total amount of GH and IGF-I in the ULF were 11.5 and $17.4 \%$, respectively.

\section{Analysis of ULF IGFBP}

Ligand blot analysis was used to determine the relative abundances of IGFBP in the ULF as described (Bilby et al., 2004).

\section{Statistical Analyses}

For the period following induced ovulation, the experimental design was an incomplete factorial design to evaluate the effects of diet (i.e., FO vs. control-fed cows), pregnancy status (i.e., pregnant vs. cyclic cows fed the control diet), and bST (i.e., bST vs. no-bST injections in cyclic control diet, cyclic FO, and pregnant control diet cows). There were no pregnant cows fed FO that received either bST or no bST. For the period following calving to the time of presynchronization or to the time of induced ovulation (i.e., depending upon the measured experimental response), only the main effect of $\operatorname{diet}$ (FO vs. control) was examined.

All variables analyzed before presynchronization as well as BCS, BW, and milk production for the entire study were analyzed using homogeneity of regression analyses for polynomial response curves utilizing the GLM procedure (SAS Inst. Inc, Cary, NC). Regression analyses were performed to determine the best-fit curves among treatments in relation to DIM, and the regressions that did not differ among treatments were pooled to characterize the response as related to DIM. Linear, quadratic, cubic, quartic, and quintic curves were tested. All variables were analyzed with the main effects of treatment, DIM, and the interaction of treatment $\times$ DIM. Milk production response was adjusted for parity. Cow within treatment or treatment $\times$ parity were considered to be random.

Pregnancy rates were analyzed using the $\chi^{2}$ and logistic regression procedures to examine the main effect of bST. The main effect of bST injection on conceptus size $(\mathrm{cm})$, IFN $-\tau$ protein content of ULF, and IFN- $\tau$ mRNA concentration in the conceptuses were evaluated utilizing the GLM procedure of SAS. The ovarian responses were analyzed using the GLM procedure of SAS testing the main effects of bST, pregnancy status, and the interaction of bST-pregnancy status. A separate series of analyses examined effects of bST, FO, and the interaction of bST $\times$ FO. Number of CL was used as a covariate for analysis of CL volume on d 17 post-AI.

During the postovulatory period, numbers of follicles and CL, as well as diameters of the largest follicle, and volume of CL tissue were analyzed by using the Mixed model procedure of SAS (Littell et al., 1996). This procedure applies methods based on the mixed model with special parametric structure on the covariance matrices. The data were tested to identify the covariance structure that provided the best fit for the data. Covariance structures tested included compound symmetry, autoregressive order 1 , and unstructured. The covariance structure used was autoregressive order 1 . Cow within bST and pregnancy status or bST and FO were random effects in the model. The 2 mathematical models used to evaluate treatment effects were: 1) bST, pregnancy status, day, and higher order interactions and 2) bST, FO, day, and higher order interactions. Volume of CL tissue was adjusted for CL number as a covariate.

Plasma hormone concentrations were analyzed using the homogeneity of regression procedure (procedure GLM; Wilcox et al., 1990) and the repeated measures analysis in the Mixed model procedure as described previously. The model included effects of bST, pregnancy status, and day or bST, FO, and day, plus higher order interactions using a statement specifying cow nested within bST and pregnancy status or cow nested within bST and FO as being random. Concentrations of plasma hormone at time of AI were used as a covariate for all respective plasma hormone concentrations during the postovulatory period. The PDIFF option in the Mixed model procedure of SAS was used to obtain the probability values for differences between treatments on particular days when tests were significant for $\mathrm{bST} \times$ pregnancy status $\times$ day and for $\mathrm{bST} \times \mathrm{FO} \times$ day interactions. 


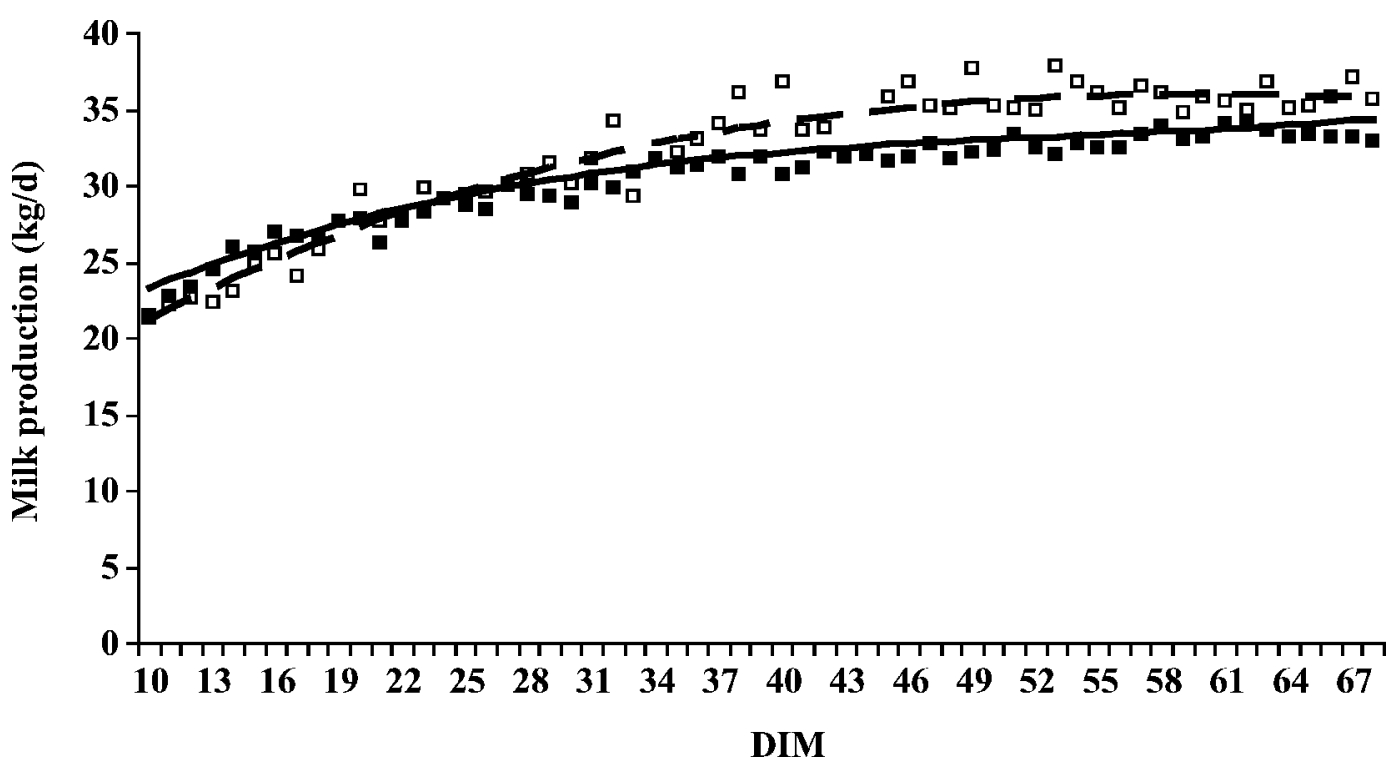

Figure 1. Regression analysis (third-order curves) of daily milk production starting 10 DIM until the start of bST treatment and timed AI for cows fed either 0 (least squares means: $\square$ ) or 1.9\% (least squares means: $\square$ ) calcium salt of fish oil-enriched lipid diets. Pattern of regression curves differed $(P<0.01)$. Regression equations: $1.9 \%$ Fish Oil: $\hat{\mathrm{y}}=13.12+0.923 \mathrm{x}-0.0117 \mathrm{x}^{2}+0.000045 \mathrm{x}^{3} ; 0 \%$ Fish Oil: $\hat{\mathrm{y}}=$ $16.51+0.808 \mathrm{x}-0.0137 \mathrm{x}^{2}+0.000085 \mathrm{x}^{3}, \mathrm{R}_{\mathrm{reg}}^{2}=0.46 ;$ where $\hat{\mathrm{y}}=$ milk production and $\mathrm{x}=\mathrm{DIM}$.

Abundances of IGF-I, IGF-II, IGFBP-2, and IGFBP3 mRNA in Northern blots were analyzed by using the GLM procedure of SAS. Main effects of treatment (no bST-C, bST-C, no bST-P, bST-P, no bST-FO-C, bSTFO-C), gel, and the interaction of treatment $\times$ gel were examined with the abundance values for GAPDH mRNA used as a covariate to adjust for loading gel differences. Predesigned orthogonal contrasts were used to compare treatment means (bST, pregnancy status, and bST $\times$ pregnancy status interaction, or bST, $\mathrm{FO}$, and $\mathrm{bST} \times \mathrm{FO}$ interaction).

Total contents of GH, IGF-I, IGFBP-3, and IGFBP4 in ULF were analyzed by using the GLM procedure of SAS. The mathematical models included the main effects of treatment (C, FO, P, bST-FO, bST-C, and bST-P) and orthogonal contrasts were used to compare treatment means (bST, pregnancy status, and bST $\times$ pregnancy status interaction or bST, FO, and bST $\times$ FO interaction).

\section{RESULTS}

\section{Effects of FO Before Ovulation Synchronization}

Regression analysis did not detect a difference between treatments for BW or BCS. Body weight followed a cubic pattern as described by the following equation: $\hat{y}=630.87-1.999 x+0.0443 x^{2}-0.00025 x^{3}$, where $\hat{y}=$ BW and $\mathrm{x}=\mathrm{DIM}$ (i.e., 0 to 40 DIM; $P<0.01, \mathrm{R}_{\mathrm{reg}}^{2}=$ 0.18). The BCS followed a quartic pattern as described by the following equation: $\hat{y}=3.35-0.036 x+0.0012 x^{2}$ $-0.000015 x^{3}+0.000000065 x^{4}$, where $\hat{y}=$ BCS and $x=$ DIM (i.e., 0 to 40 DIM; $P<0.01, \mathrm{R}_{\mathrm{reg}}^{2}=0.28$ ). Thirdorder milk production curves between cows fed the FO and control diets differed with cycling cows fed FO producing as much as $3 \mathrm{~kg}$ more milk than cyclic controlfed cows (Figure 1).

Number of class 1 follicles was greater $(P<0.05)$ in cows fed FO than control-fed cows $(34.5 \pm 2.4$ vs. 28.0 \pm 1.2 , respectively). Number of class 2 follicles (3.9 \pm $0.3)$, class 3 follicles $(2.3 \pm 0.2)$, number of CL ( $0.5 \pm$ $0.1)$, CL volume $\left(199 \pm 19 \mathrm{~mm}^{3}\right)$, size of the largest follicle $(15.1 \pm 0.8 \mathrm{~mm})$, size of the nonpregnant uterine horn $(2.9 \pm 0.1 \mathrm{~cm})$, and size of the previous pregnant uterine horn $(3.1 \pm 0.1 \mathrm{~cm})$ were not affected by FO. As expected, number of follicles, number of CL, CL size, size of largest follicle, size of nonpregnant uterine horn, and size of previous pregnant uterine horn differed ( $P$ $<0.01$ ) according to DIM. Regression curves, however, did not differ between treatments in relation to DIM (i.e., $\mathrm{x}=14$ to $42 \mathrm{DIM}$ ) so the overall pooled regression equations and $R^{2}$ values are presented for the respective variables (i.e., $\hat{\mathrm{y}})$. Numbers of class $1(\hat{\mathrm{y}}=25.02+0.263 \mathrm{x}$, $\left.P<0.01, \mathrm{R}_{\text {reg }}^{2}=0.08\right)$ and class 2 follicles $(\mathrm{y}=2.51+$ $0.0496 \mathrm{x}, P<0.01, \mathrm{R}_{\mathrm{reg}}^{2}=0.05$ ) increased linearly with DIM. Regression analysis revealed a second-order curvilinear relationship for number of class 3 follicles $(\hat{\mathrm{y}}=$ $\left.-0.03+0.135 \mathrm{x}-0.0019 \mathrm{x}^{2}, P<0.01, \mathrm{R}_{\mathrm{reg}}^{2}=0.05\right)$, number of CL $\left(\hat{\mathrm{y}}=-1.11+0.096 \mathrm{x}-0.0014 \mathrm{x}^{2}, P<0.01, \mathrm{R}_{\mathrm{reg}}^{2}=\right.$ 


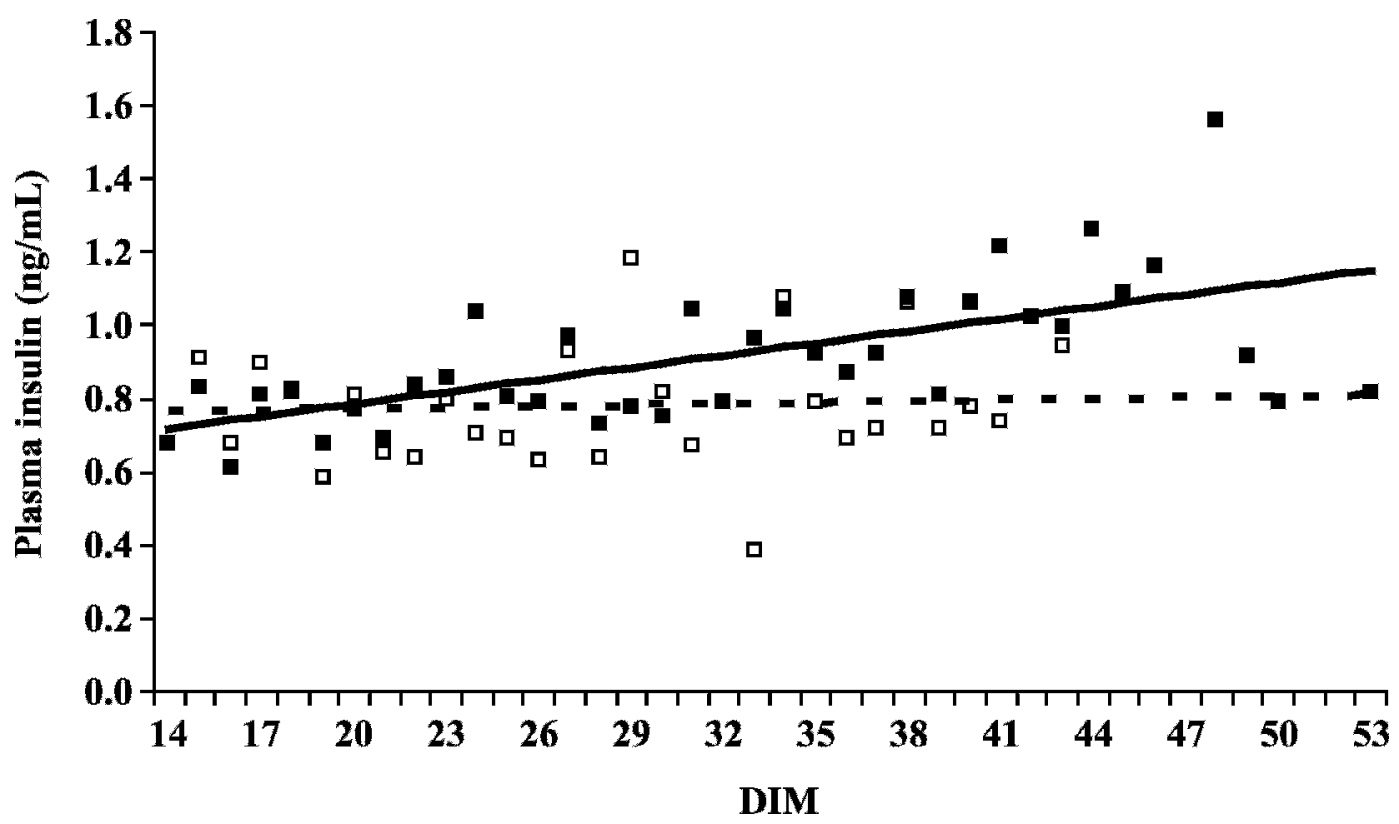

Figure 2. Linear regression of plasma insulin concentrations for cows fed fish oil-enriched lipid (FO) at 0 (least squares means: $\mathbf{0})$ or 1.9\% (least squares means: $\square$ ) of dietary DM from 14 to 53 DIM. Feeding FO decreased $(P<0.01)$ plasma insulin concentrations compared with control cows in relation to DIM. Regression equations: $0 \%$ Fish Oil: $\hat{y}=0.56+0.011 x ; 1.9 \%$ Fish Oil: $\hat{y}=0.75+0.0012 x, R_{\text {reg }}^{2}=0.14$; where $\hat{y}=$ insulin concentration and $\mathrm{x}=$ DIM.

0.13), CL size $\left(\hat{\mathrm{y}}=-496.60+40.356 \mathrm{x}-0.5372 \mathrm{x}^{2}, P<\right.$ $\left.0.01, \mathrm{R}_{\text {reg }}^{2}=0.17\right)$, and size of largest follicle $(\hat{\mathrm{y}}=9.12$ $\left.+0.297 \mathrm{x}-0.00242 \mathrm{x}^{2}, P<0.01, \mathrm{R}_{\mathrm{reg}}^{2}=0.08\right)$ in relation to DIM. The size $(\mathrm{cm})$ of the previous pregnant $(\hat{\mathrm{y}}=$ $\left.4.25-0.044 \mathrm{x}, P<0.01, \mathrm{R}_{\mathrm{reg}}^{2}=0.19\right)$ and nonpregnant uterine horns ( $\hat{\mathrm{y}}=3.46-0.023 \mathrm{x}, P<0.01, \mathrm{R}_{\mathrm{reg}}^{2}=0.08$ ) decreased linearly with DIM.

Insulin concentrations increased $(P<0.01)$ linearly with increasing DIM for the cyclic control-fed cows at a faster rate compared with cows fed FO (Figure 2). Regression of plasma GH, IGF-I, and progesterone concentrations on DIM did not detect differences between dietary treatments. The overall pooled regression equations with DIM (i.e., $\mathrm{x}=14$ to $53 \mathrm{DIM}$ ) are presented. Both GH and IGF-I concentrations had a linear relationship to DIM with GH concentrations decreasing $(\hat{\mathrm{y}}=$ $\left.7.46-0.042 \mathrm{x}, P<0.01, \mathrm{R}_{\mathrm{reg}}^{2}=0.04\right)$ and IGF-I concentrations increasing $\left(\hat{\mathrm{y}}=85.27+0.922 \mathrm{x}, P<0.01, \mathrm{R}_{\mathrm{reg}}^{2}=\right.$ $0.05)$ over time. A second-order curve was detected for progesterone concentrations in relation to DIM (progesterone: $\hat{\mathrm{y}}=-3.54+0.281 \mathrm{x}-0.0036 \mathrm{x}^{2}, P<0.01, \mathrm{R}_{\mathrm{reg}}^{2}=$ $0.19)$. Pattern for accumulated progesterone concentrations $\left(\hat{\mathrm{y}}=4.90-0.714 \mathrm{x}+0.0287 \mathrm{x}^{2}-0.00017 \mathrm{x}^{3}, P<\right.$ $\left.0.01, R_{\text {reg }}^{2}=56.04\right)$, days to first ovulation $(23.5 \pm 2.4$ d), and percentage of cows cycling before the start of presynchronization $(51.9 \pm 13.3 \%)$ were not different between cows fed diets of 0 or $1.9 \%$ FO.

\section{Interaction of bST, Diet, and Pregnancy Status on Plasma Hormones and Ovarian Structures}

Treatment with bST increased $(P<0.01)$ milk production as described by second-order curves (i.e., bST vs. no bST) during days of the synchronized estrous cycle (Figure 3). The bST given on $\mathrm{d} 0$ and 11 relative to AI increased milk production as much as $7 \mathrm{~kg} / \mathrm{d}$ compared with cows not injected with bST.

No differences among treatments were detected for the mean number of class 3 follicles $(2.6 \pm 0.4)$, size of the largest follicle $(19.1 \pm 1.0 \mathrm{~mm})$, size of the second wave follicle $(10.8 \pm 1.3 \mathrm{~mm})$, and number of CL ( $1.1 \pm$ $0.1)$. Pregnant cows tended $(P<0.10)$ to have greater volume of CL tissue compared with cyclic cows fed the control diet $\left(10,742 \pm 722\right.$ vs. $\left.8,803 \pm 681 \mathrm{~mm}^{3}\right)$. From d 9 to 16 after AI, number of class 1 follicles was influenced by bST injection and pregnancy status. Of those cows fed the control diet, giving bST to cows that were pregnant increased the number of class 1 follicles, whereas those that were pregnant not receiving bST had a decreased number of class 1 follicles. Cyclic cows had no change in this number $(\mathrm{bST} \times$ pregnancy $\times$ day interaction; $P<0.05$ ). Pregnant cows tended (pregnancy status $\times$ day interaction; $P<0.10$ ) to have more class 2 follicles on $\mathrm{d} 13$ and 16 compared with cyclic cows fed the control diet $(6.3 \pm 0.8,5.3 \pm 0.8$ vs. $3.2 \pm 0.7,3.4 \pm$ 0.7 , respectively), but numbers were not different at the other days. 


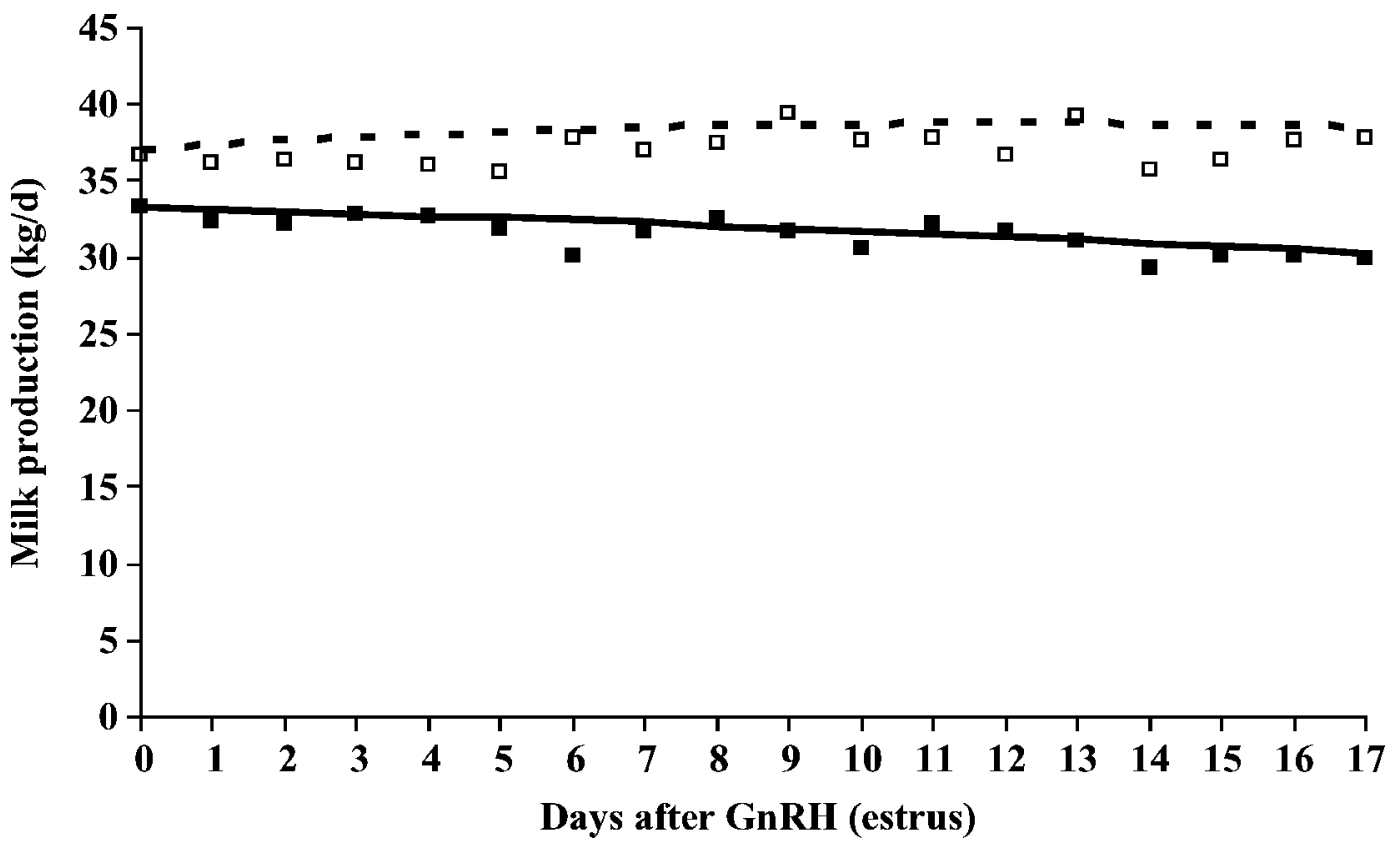

Figure 3. Regression analysis (second-order curves) of daily milk production from d 0 to 17 of a synchronized estrous cycle (d 0 ) for cyclic and pregnant cows fed the control diet and injected with bST (least squares means: $\square$ ) or not (least squares means: $\mathbf{\square})$ on $d 0$ and 11. Pattern of regression curves differed $(P<0.01)$. Regression equation: bST: $\hat{\mathrm{y}}=33.30-0.125 \mathrm{x}-0.0029 \mathrm{x}^{2} ; \mathrm{no}$ bST: $\hat{\mathrm{y}}=37.05+0.281 \mathrm{x}-$ $0.0118 \mathrm{x}^{2} ; \hat{\mathrm{y}}=$ milk production and $\mathrm{x}=$ days after GnRH (estrus).

Feeding FO did not alter progesterone concentrations in plasma. Injections of bST reduced $(P<0.05)$ progesterone concentrations in plasma for cyclic and pregnant cows fed the control diet relative to comparable cows not injected with bST (Figure 4).

The bST injections increased $(P<0.01)$ mean concentration of plasma GH in bST-C, bST-FO, and bST-P cows compared with the non-bST injected cows (no bSTC, no bST-FO-C, and no bST- P cows; $14.2 \pm 1.1,20.0$ \pm 1.2 and $20.5 \pm 1.2 \mathrm{ng} / \mathrm{mL}$ vs. $6.0 \pm 1.1,6.7 \pm 1.2$ and $5.9 \pm 1.3 \mathrm{ng} / \mathrm{mL}$, respectively; Figure 5). Interactions were detected $(P<0.05)$ between cyclic cows fed the control or FO diet and also between cyclic cows fed the control diet and pregnant cows. Administration of bST increased mean GH concentrations in bST-C, but not to the extent of bST-FO-C and bST-P cows (14.2 \pm 1.1 vs. $20.0 \pm 1.2$ and $20.5 \pm 1.2$, respectively; Figure 5). Associated with increases in plasma GH were increases $(P<0.01)$ in IGF-I for both bST-C and bST-P groups in contrast with no bST-C and no bST-P groups (211 \pm 17 and $261 \pm 18 \mathrm{ng} / \mathrm{mL}$ vs. $152 \pm 17$ and $150 \pm 19 \mathrm{ng} /$ $\mathrm{mL}$ respectively; Figure 6). Patterns of plasma IGF-I for the bST-P and bST-C groups followed different fourthorder responses $(P<0.05)$, with the pregnant cows maintaining their peak concentration during the last week of measurement (pregnancy $\times$ day interactions; Figure 6). In addition, injecting bST into cows fed the control diet resulted in a gradual rise in concentration of plasma IGF-I from d 0 to 8 followed by a gradual decrease compared with a fairly constant and reduced $(P<0.05)$ concentration of circulating IGF-I in cows injected with bST and fed FO (bST-C vs. bST-FO-C $\times$ day interaction; Figure 6). Mean concentrations of plasma insulin decreased $(P<0.01)$ in both no bST-FO$\mathrm{C}$ and bST-FO-C treatments compared with both no bST-C and bST-C cows $(0.9 \pm 0.1$ and $1.0 \pm 0.1$ vs. 1.5 \pm 0.1 and $1.2 \pm 0.1$ respectively). In contrast, bST tended $(P \leq 0.10)$ to reduce insulin concentrations in cyclic control-fed cows with no effect in FO-fed cows (1.5 to $1.2 \pm 0.1$ vs. 1.0 to $0.9 \pm 0.1$, respectively; $\mathrm{bST} \times$ fish oil interaction).

\section{Ovarian, Uterine, and Pregnancy Responses at d 17}

No differences were detected among treatments for $\mathrm{CL}$ weight. Injecting bST tended $(P=0.10)$ to reduce number of CL in the cyclic control-fed cows while increasing the number of CL in the fish oil-fed cows and in the pregnant control-fed cows (Table 3). Volume of the CL was increased $(P<0.01)$ in pregnant compared with cyclic cows fed the control diet (11,171 vs. 7,686 $\mathrm{mm}^{3}$; Table 3).

Volumes and protein content of ULF did not differ between pregnancy statuses, diets, or bST treatment. Total amounts of GH or IGF-I in the ULF did not differ (Table 3). 


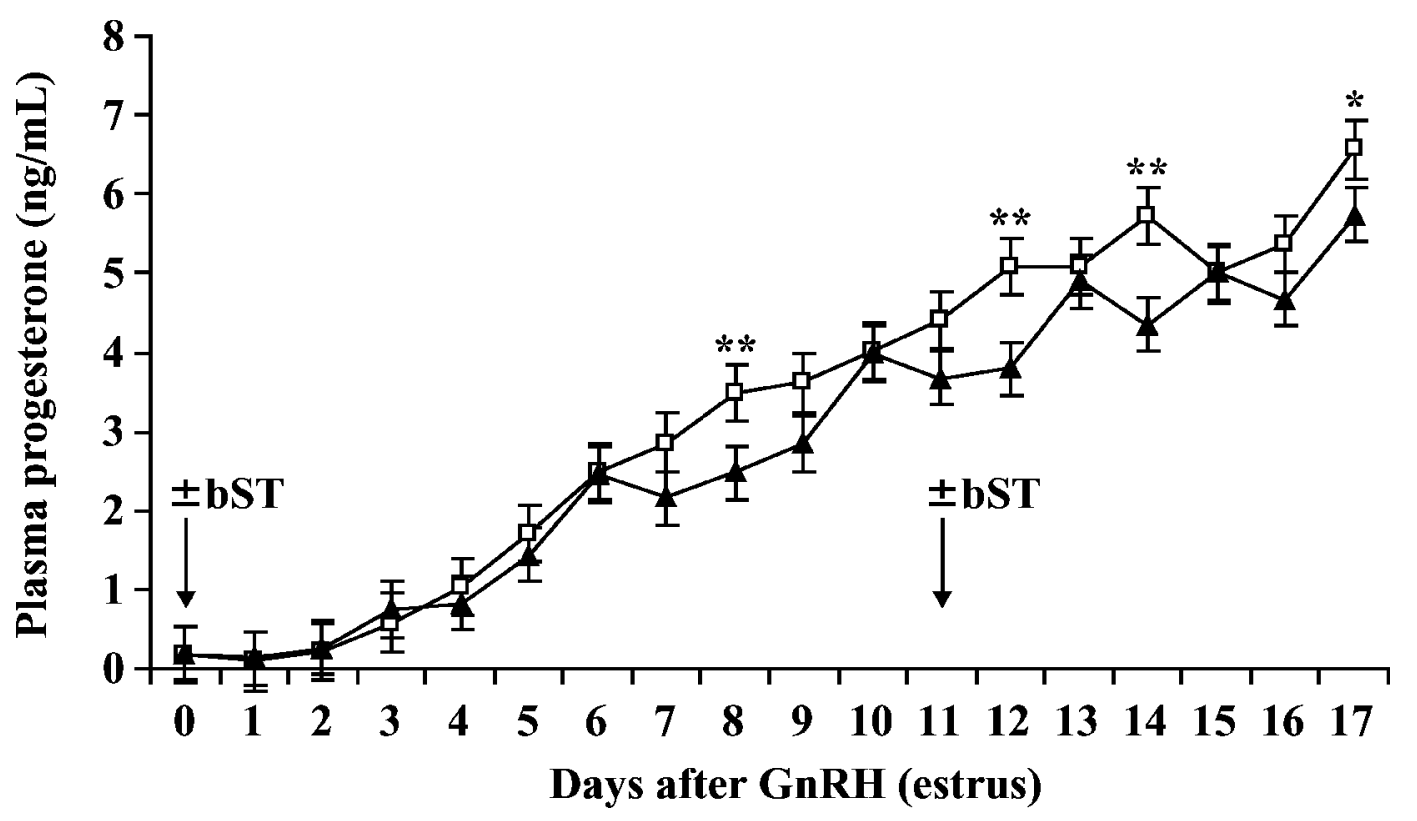

Figure 4. Concentrations of plasma progesterone of cyclic and pregnant cows not given bST $(\mathrm{n}=10$; $\square)$ and those given bST $(\mathrm{n}=11$; A) collected from d 0 to 17 of a synchronized estrous cycle differed $(P<0.05)$. All cows were fed the control diet. Concentrations of progesterone at days designated differed: $* P<0.10 ; * * P<0.05$.

Pregnancy rate at $d 17$ tended $(P<0.09)$ to increase in response to bST $(83.3 \%$; 5 of 6$)$ compared with nonbST-treatment $(40.0 \% ; 4$ of 10$)$. Not only did pregnancy rates tend to increase in bST-treated cows, but conceptuses that survived to $\mathrm{d} 17$ in the bST-P cows tended $(P<0.09)$ to be longer $(45.4 \pm 4.5 \mathrm{~cm})$ than no bST-P cows $(34.3 \pm 5.1 \mathrm{~cm})$. Furthermore, the amount of IFN$\tau$ in the ULF from bST-P cows was almost 2 times greater $(P<0.05)$ at $9.4 \mu \mathrm{g} /$ total ULF compared with $5.3 \mu \mathrm{g} /$ total ULF in no bST-P cows (Table 3). Amount of IFN- $\tau$, however, did not differ when adjusted for conceptus length as a covariate. Relative abundance of IFN- $\tau$ mRNA in conceptus tissue and amount of interferon-stimulated gene-17 protein in the endometrial tissue on 17 was not affected by bST injections (Table 3 ).

The GHR-1A was undetectable in the endometrium of all cows. The mRNA transcript sizes for IGF-I, IGFII, IGFBP-2, and IGFBP-3 were 7.5, 4.6, 1.7, and 2.8 $\mathrm{kb}$, respectively. The IGF-I mRNA was less $(P<0.01)$ in pregnant cows and tended $(P<0.06)$ to be less in cycling cows fed FO compared with cows fed the control $\operatorname{diet}$ (Table 3). Within control-fed cows, pregnancy and bST increased $(P<0.01)$ IGF-II mRNA. Injecting bST increased (diet $\times$ bST interaction; $P<0.01$ ) endometrial IGF-II mRNA of cycling cows fed the control diet, but not those fed the FO.

When only cycling cows (both control-fed and FO-fed cows) were considered, those injected with bST had less $(P<0.05)$ IGFBP-2 mRNA in their endometrial tissue than those not injected with bST [54 vs. 99 arbitrary units (AU), respectively]. Injecting bST into cows that became pregnant (i.e., bST-P) resulted in greater (bST $\times$ pregnancy interaction, $P<0.05)$ IGFBP-2 mRNA in their endometrium than no bST-P cows (121 vs. $79 \mathrm{AU}$ ), but injecting bST into cycling control-fed cows resulted in less (bST by pregnancy interaction, $P<0.05$ ) IGFBP2 mRNA than those no bST-C cows (51 vs. 80 AU). A decrease $(P<0.05)$ was detected in IGFBP-2 mRNA among bST-treated cyclic cows fed a control or fish oil diet; however, an interaction $(P<0.05)$ also occurred between pregnant cows and cyclic cows fed a control diet with bST increasing IGFBP-2 mRNA in pregnant cows, but decreasing IGFBP-2-mRNA in cyclic controlfed cows. No differences among treatments were detected for IGFBP-3 mRNA.

Total ULF protein did not differ among treatments. Four distinct IGFBP bands were detected from 44 to $24 \mathrm{kDa}$. Treatment did not affect IGFBP-3 (44 and 40 $\mathrm{kDa}$ ) or IGFBP-4 (28 and $24 \mathrm{kDa}$; Table 3 ) probably because of considerable variability among cows.

\section{Simple and Partial Correlations for the GH-IGF System at d 17}

Correlations were not detected between IGF-I in ULF and circulating concentrations of IGF-I or between GH in the ULF and circulating concentrations of plasma $\mathrm{GH}$ at $\mathrm{d}$ 17. A series of simple (r) and partial (pr) corre- 
Table 3. Least squares means and pooled SE for conceptus size, IFN- $\tau$ mRNA (mean fold effect), IFN- $\tau$ [ $\mu$ g/total uterine luminal flushing (ULF)], IFN-stimulated gene-17 (ISG-17) protein number of corpora lutea (CL), CL tissue volume $\left(\mathrm{mm}^{3}\right)$, CL weight (g), uterine endometrial mRNA, ULF protein expression, and hormone concentration at d 17 after a synchronized estrus (d 0) in lactating cyclic (C) cows fed a control diet, pregnant (P) cows fed a control diet, and cyclic cows fed a fish oil-enriched lipid (FO) diet and injected with or without bST on d 0 and d 11

\begin{tabular}{|c|c|c|c|c|c|c|c|c|c|c|c|c|c|}
\hline \multirow[b]{2}{*}{ Response $^{1}$} & \multicolumn{6}{|c|}{ Treatment $^{2}$} & \multirow[b]{2}{*}{$\mathrm{SE}$} & \multicolumn{3}{|c|}{ Contrast $^{3}$ Cyclic } & \multicolumn{3}{|c|}{ Contrast $^{3}$ Pregnant } \\
\hline & $\begin{array}{l}\text { No } \\
\text { bST-C }\end{array}$ & bST-C & $\begin{array}{l}\text { No bST- } \\
\text { FO-C }\end{array}$ & bST-FO-C & No bST-P & bST-P & & FO & bST & $\begin{array}{l}\mathrm{bST} \\
\times \mathrm{FO}\end{array}$ & $\mathrm{P}$ & $\mathrm{bST}$ & $\begin{array}{l}\mathrm{bST} \\
\times \mathrm{P}\end{array}$ \\
\hline Pregnancy rate, $\%$ & - & - & - & - & $40(4 / 10)$ & $83(5 / 6)$ & - & - & - & - & - & $\dagger$ & - \\
\hline Conceptus length, cm & - & - & - & - & 34.3 & 45.4 & 4.8 & - & - & - & - & $\dagger$ & - \\
\hline IFN $-\tau$ mRNA & - & - & - & - & 1.8 & 1.6 & 0.5 & - & - & - & - & NS & - \\
\hline IFN- $\tau, \mu \mathrm{g} /$ total ULF & - & - & - & - & 5.3 & 9.4 & 1.2 & - & - & - & - & * & - \\
\hline ISG-17 protein & - & - & - & - & 11.0 & 10.0 & 3.0 & - & - & - & - & NS & - \\
\hline Number of CL & 1.4 & 1.0 & 1.0 & 1.3 & 1.0 & 1.2 & 0.2 & NS & NS & $\dagger$ & $\mathrm{NS}$ & NS & $\dagger$ \\
\hline CL volume, $\mathrm{mm}^{3}$ & 7,242 & 8,130 & 8,641 & 10,507 & 12,568 & 9,775 & 1,404 & $\mathrm{NS}$ & NS & NS & $* *$ & NS & NS \\
\hline CL weight, $\mathrm{g}$ & 5.5 & 5.9 & 6.7 & 6.6 & 7.1 & 6.2 & 0.7 & NS & NS & NS & NS & NS & NS \\
\hline \multicolumn{14}{|l|}{ Endometrium IGF system } \\
\hline IGF-I mRNA, AU & 75 & 76 & 71 & 71 & 67 & 67 & 2.1 & $\dagger$ & NS & NS & $* *$ & NS & $\mathrm{NS}$ \\
\hline IGF-II mRNA, AU & 76 & 82 & 82 & 80 & 81 & 86 & 1.3 & $\dagger$ & NS & ** & $* *$ & $* *$ & NS \\
\hline IGFBP-2 mRNA, AU & 80 & 51 & 118 & 58 & 79 & 121 & 10.0 & NS & $*$ & NS & $*$ & NS & $*$ \\
\hline IGFBP-3 mRNA, AU & 18 & 18 & 17 & 15 & 14 & 17 & 1.8 & NS & NS & $\mathrm{NS}$ & NS & NS & NS \\
\hline \multicolumn{14}{|l|}{ ULF IGF system } \\
\hline $\mathrm{GH}, \mathrm{ng} / \mathrm{ULF}$ & 8 & 9 & 13 & 17 & 9 & 8 & 4.7 & NS & NS & NS & NS & NS & NS \\
\hline IGF-I, ng/ULF & 296 & 244 & 396 & 496 & 219 & 145 & 164 & NS & NS & NS & $\mathrm{NS}$ & NS & $\mathrm{NS}$ \\
\hline IGFBP-3, AU & 43 & 37 & 124 & 60 & 58 & 14 & 41 & NS & NS & NS & NS & NS & NS \\
\hline IGFBP-4, AU & 31 & 32 & 84 & 57 & 71 & 13 & 30 & NS & NS & NS & NS & NS & NS \\
\hline
\end{tabular}

${ }^{1}$ IGFBP = Insulin-like growth factor binding protein; GH = growth hormone. Arbitrary units (AU) were generated by densitometry. The mRNA results were adjusted using glyceraldehyde-3-phosphate dehydrogenase as a covariate.

${ }^{2}$ No bST-C = No bST cyclic, bST-C = bST-cyclic, No bST-FO-C = No bST-Fish Oil-cyclic, bST-FO-C = bST-fish oil cyclic, No bST-P = No bST-Pregnant, bST-P = bST-pregnant.

${ }^{3}$ Contrasts for cyclic cows were: FO $=$ all FO-fed cows vs. all cyclic-control fed cows, bST $=$ all cyclic cows injected with bST vs. all cylic cows not given bST, and bST $\times$ FO interaction. Contrasts for pregnant cows were: $\mathrm{P}=$ all pregnant cows vs. cyclic control-fed cows, and bST = all pregnant and cyclic cows fed the control diet and injected with bST vs. all pregnant and cyclic cows fed the control diet without bST, and bST $\times \mathrm{P}$ interaction.

$$
\dagger P \leq 0.10 ; * P \leq 0.05 ; * * P \leq 0.01 \text {. }
$$




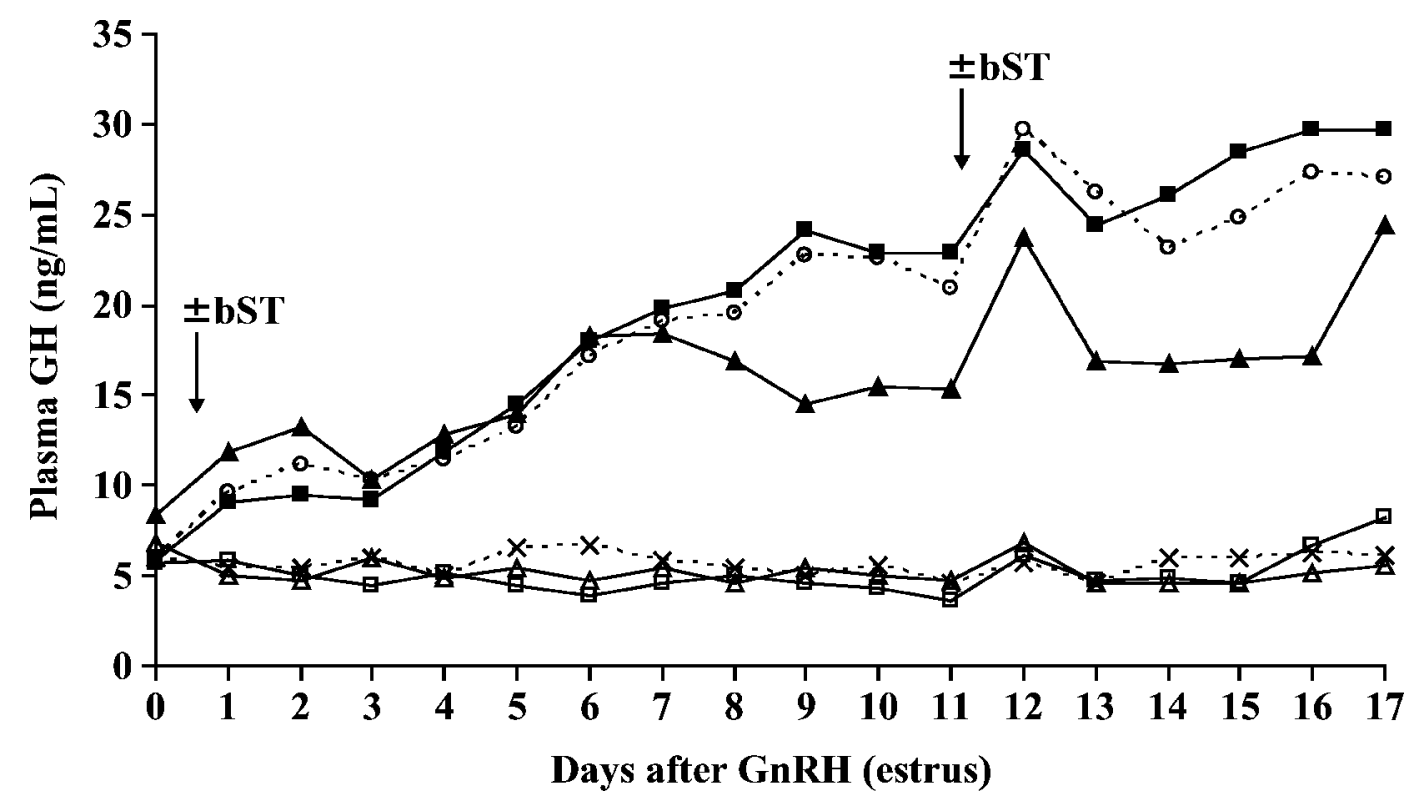

Figure 5. Profiles of plasma growth hormone (GH) concentrations of cyclic cows fed control diet (no bST; $\triangle$ ), cyclic cows fed control diet with bST injections ( $\mathbf{\Delta})$, cyclic cows fed FO (---X---), cyclic cows fed FO with bST injections (---O---), pregnant cows fed control diet (no bST; $\square$ ), and pregnant cows fed control diet with bST injections ( $\mathbf{\square})$ from d 0 to 17 of a synchronized estrous cycle. All 3 groups of cows given bST had greater mean GH concentrations than cows not injected with bST $(P<0.01)$. Of those given bST, cows fed FO and pregnant cows had greater $(P<0.05)$ mean GH concentrations than cyclic cows fed the control diet. Pooled standard errors for bST-treated cows $=3.31$ and non-bST-treated cows $=1.13$.

lations, however, were detected $(P \leq 0.05)$. Concentrations of plasma GH were correlated positively with IGF$\mathrm{I}$ in plasma $[\mathrm{r}=0.37$; partial correlation adjusted for treatment $(\mathrm{pr}=0.51)$ ]. The IGF-I in plasma was associated positively with insulin $(r=0.38 ; \mathrm{pr}=0.46)$ and plasma progesterone $(r=0.36 ; \mathrm{pr}=0.72)$. Progesterone concentrations in plasma were correlated positively with plasma insulin concentrations $(\mathrm{r}=0.42 ; \mathrm{pr}=0.56)$ and negatively correlated with IGFBP-4 in the ULF $(\mathrm{pr}=-0.44)$. The GH in the ULF was associated positively with IGF-I in the ULF $(\mathrm{r}=0.94 ; \mathrm{pr}=0.94)$. The IGFBP-2 mRNA was positively correlated with IGF-I mRNA $(\mathrm{pr}=0.49)$, IGF-II mRNA $(\mathrm{r}=0.53 ; \mathrm{pr}=0.50)$, IGFBP-3 mRNA ( $\mathrm{r}=0.53 ; \mathrm{pr}=0.57)$, and concentrations of plasma insulin $(\mathrm{r}=0.51 ; \mathrm{pr}=0.62)$. Amount of IGFBP-3 protein was associated positively with IGFBP4 protein in the ULF $(r=0.60 ; \mathrm{pr}=0.57)$. The IGF-I mRNA expression was associated positively with IGFII mRNA expression $(\mathrm{r}=0.59$; $\mathrm{pr}=0.88)$.

\section{DISCUSSION}

Dietary supplementation with FO increased milk production compared with cows fed lipid in the form of whole cottonseeds during the postpartum period before TAI or bST treatment (Figure 1). Although milk yield increased, BCS and BW were not influenced by diet.
Pregnancy rate, length of conceptus, and amount of IFN- $\tau$ in ULF tended to or were increased in response to bST administration at TAI and again $11 \mathrm{~d}$ later following an Ovsynch protocol (Table 3). Beneficial effects of bST on early embryo development seem to be extended to later stages of development approaching the critical period when the conceptus secretes IFN- $\tau$ for maintenance of the CL. Because of a tendency for bSTinduced increase in conceptus length, amount of IFN$\tau$ in ULF increased and may have contributed to the tendency for bST-induced increase in pregnancy rate. Injections of bST increased IGF-I concentrations in plasma (Figure 6), which may compensate for an inadequate concentration of IGF-I in high-producing dairy cows resulting in improved fertility. Bilby et al. (2004) reported decreased pregnancy rate in nonlactating dairy cows when bST was injected at TAI and $11 \mathrm{~d}$ later. This negative effect seemed to result from hyperstimulation of IGF-I concentrations. Pregnancy rate was high in the non-bST-treated control group in that study, whose basal concentrations of plasma IGF-I approximated those observed in the present study in lactating cows injected with bST. In contrast, lactating control cows with lower fertility had low concentrations of IGFI. In other target populations of cattle, such as nonlactating dairy heifers (Rorie et al., 2004) and lactating beef cattle (Bilby et al., 1999), in which plasma IGF-I 


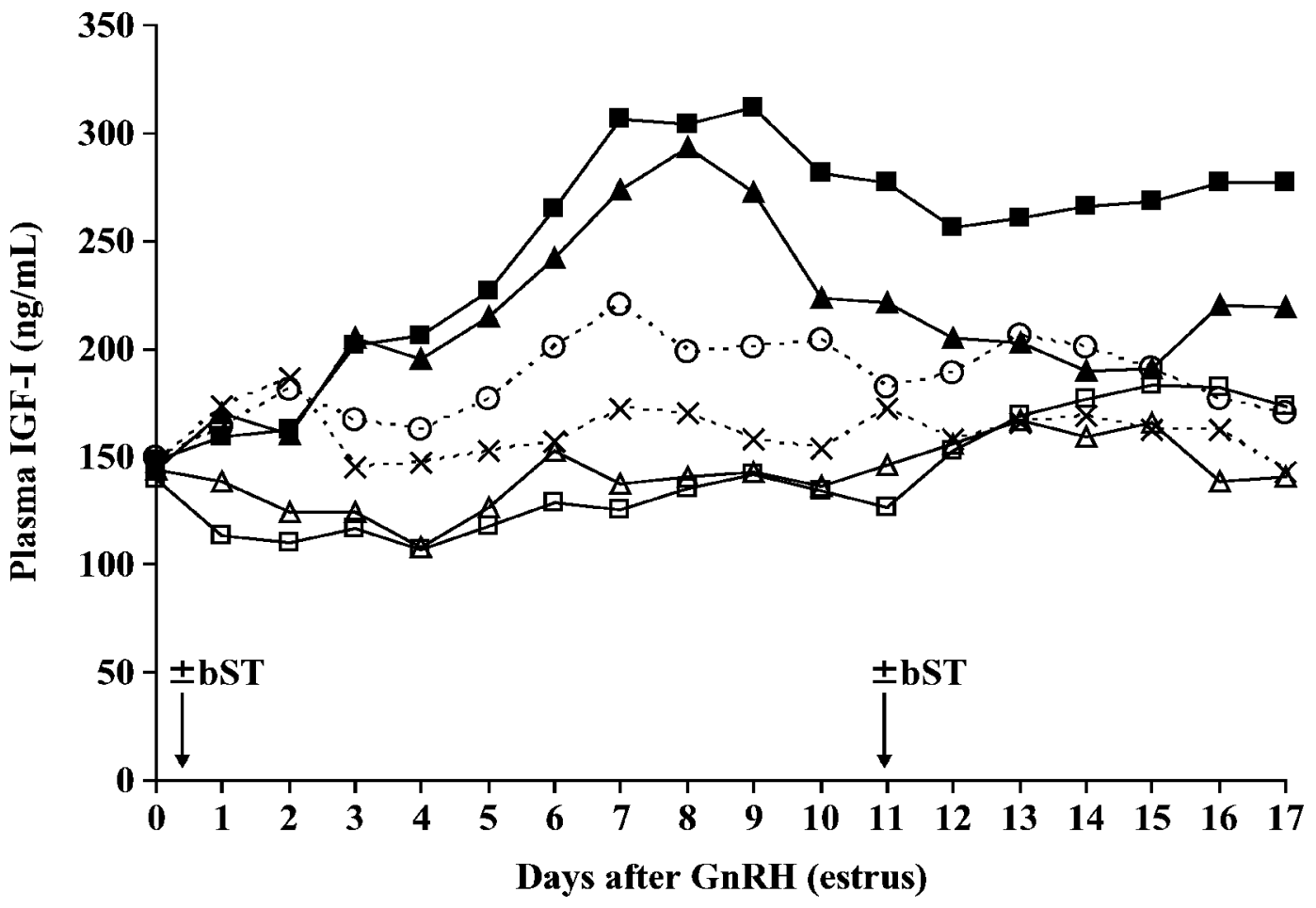

Figure 6. Profiles of plasma IGF-I concentrations of cyclic cows fed control diet (no bST; $\triangle$ ), cyclic cows fed control diet with bST injections $(\mathbf{\Lambda})$, cyclic cows fed FO (---X---), cyclic cows fed FO with bST injections (---O---), pregnant cows fed control diet (no bST; $\square)$, and pregnant cows fed control diet with bST injections ( $)$ from d 0 to 17 of a synchronized estrous cycle. All 3 groups of cows given bST had greater $(P$ $<0.01)$ mean IGF-I concentrations than cows not injected with bST. The FO-fed cows injected with bST had lower $(P<0.05)$ IGF-I plasma concentrations and pregnant cows injected with bST had greater $(P<0.05)$ IGF-I plasma concentrations than cyclic cows fed the control diet with bST injections as detected by homogeneity of regression. Pooled standard errors for bST-treated cows $=29.9$ and non-bST-treated cows $=22.2$.

would be at greater concentrations than in lactating dairy cattle (Bilby et al., 1999), exogenous bST seems to have no beneficial effect or even negative effects on pregnancy rate. A threshold concentration of IGF-I may exist that is associated with increased fertility, and elevation of IGF-I beyond this threshold may have a negative impact on pregnancy rate. The reason for the beneficial effects of bST injections in some inseminated cows and not others, may reflect differences in amongcow sensitivity to bST regarding IGF-I secretion. This sensitivity is likely influenced by physiological (i.e., lactation) and nutritional statuses. The combination of increased IGF-I concentrations and localized production of IFN- $\tau$ in bST-treated cows have profound effects on the antiluteolytic mechanisms involved with maintenance of the CL (Bilby et al., 2006a).

Injections of bST twice at an interval of $11 \mathrm{~d}$ sustained concentration of plasma GH for the entire 17-d period until slaughter as anticipated. Concentrations of GH were greater in bST-P cows and those fed FO (bSTFO-C) compared with cycling cows not fed FO (bST-C; Figure 5). Growth hormone has been shown to "cross talk" via signal transduction systems with peroxisome proliferator-activated receptor- $\alpha$, which is a nuclear transcription factor found in hepatocytes that can be activated by polyunsaturated fatty acids to activate or repress expression of various genes (Khan and Vanden Heuvel, 2003). Dietary FO, when acting through peroxisome proliferator-activated receptor- $\alpha$, may decrease GH receptor expression such that uptake and clearance of GH is reduced in bST-injected cows. This may contribute to a greater plasma concentration of GH in bSTinjected cows fed FO.

Such an effect may be reflected in a differential response of IGF-I concentrations. Indeed, concentrations of plasma IGF-I in FO-fed cows was less than either pregnant or cyclic cows when injected with bST (Figure 6 ). This may reflect decreased sensitivity of the liver to $\mathrm{GH}$ in cows fed FO and injected with bST. Milk yield increased due to bST injections as a main effect during the 17-d period before slaughter (Figure 3).

Not only did feeding FO have interacting effects on the GH-IGF-I system, but it also chronically reduced insulin concentrations in plasma throughout the experiment beginning approximately 2 wk after initiating full feeding of the FO diet (Figure 2). Feeding increasing 
amounts of calcium salts of long-chain fatty acids (Choi and Palmquist, 1996) caused a linear decrease in plasma insulin concentrations. In a review by Staples et al. (1998), decreased plasma insulin concentrations were reported in 7 of 9 studies when fat was fed. Plasma insulin concentrations reflect plasma glucose availability. The FO-induced increase in milk production may have increased glucose utilization for lactose production such that a concurrent decrease in insulin concentrations would be expected. Because plasma insulin was reduced in response to FO in the present study, GHR, GH-binding protein, and GH binding sensitivity may be reduced compared with control-fed cows, accounting for the increase in plasma GH without a subsequent rise in plasma IGF-I in FO- vs. control-fed cows. Reduction in insulin also may account for the increase in the number of class 1 follicles in FO-fed cows before ovulation synchronization. Insulin-like growth factor-I is a potent stimulator of bovine granulosa cells in vitro (Spicer et al., 1993) and bovine granulosa cells tended to produce less IGF-I when cultured with insulin and GH. Therefore, suppression of insulin through the feeding of FO may allow IGF-I to positively affect follicle development and possibly other reproductive responses.

Progesterone concentrations in plasma were unaffected by feeding FO both before and after synchronization. Treatment with bST, however, reduced progesterone from d 6 to 17 post-AI (Figure 4). Injections of bST are reported to reduce progesterone concentrations (Kirby et al., 1997) in dairy cows, which may be due to increased DMI and milk production, thereby increasing progesterone clearance (Sangsritavong et al., 2002). Pregnancy did not affect plasma progesterone concentrations from d 0 to 17 ; however, CL tissue volume was increased from d 7 to 17 and CL tissue volume was increased at the time of slaughter in pregnant (no bST$\mathrm{P}$ and bST-P) cows (Table 3).

Components of the GH-IGF system can stimulate early embryo (Moreira et al., 2002a,b) and fetal development. In this study, genes of the GH and IGF-I family were investigated to examine the effects of bST, pregnancy, and FO (Table 3). Because the current study had no pregnant cows fed FO, comparisons could not be made between FO-fed cows and pregnant cows. Differential responses between FO and cyclic control-fed cows can be made, and whether such differences reflect a pregnancy-like response can be inferred and warrants further investigation. The IGF-I mRNA in endometrial tissue decreased in pregnant cows fed the control diet and tended to decrease in cows fed FO compared with cyclic cows fed the control diet. In contrast, IGF-II mRNA was increased in control-fed cows that were either pregnant or injected with bST, and feeding FO increased IGF-II mRNA without an additive effect of bST. The IGF-I and IGF-II gene responses to FO mimicked those of the pregnant state. Perhaps FO provides a more conducive intrauterine environment for embryo development that enhances embryonic survival. Geisert et al. (1991) also showed that endometrial IGF-II mRNA increased in pregnant cows during this time as the uterus is prepared for ensuing implantation. Pregnant cows in the current study had elevated IGFBP-2 mRNA when injected with bST, but nonpregnant cows had reduced IGFBP-2 mRNA when injected with bST. The increase in IGF-II mRNA was correlated with the increase in IGFBP-2 mRNA which may be associated with an increase in IGFBP-2 protein in the endometrium to increase delivery of newly synthesized IGF-II to the overlying developing conceptus in preparation for implantation and placentation. Differential dynamics of IGF-I, IGF-II, and IGFBP-2 expression of endometrial mRNA between cyclic and pregnant cows may reflect direct conceptus-induced alterations in regulation of gene expression due to such agents as IFN- $\tau$, or indirect conceptus-induced alterations within the endometrium that effect responsiveness to bST injections and potentially diets enriched in FO. Spencer et al. (1999) demonstrated that injection of ewes with IFN- $\tau$ was necessary to induce endometrial responsiveness to placental lactogen and GH. Treatments did not differ in endometrial IGFBP-3 mRNA, which was not unexpected because IGFBP-3 is produced mainly in the liver and is a major transporter of IGF-I in the peripheral circulation. Not only were there no treatment differences for IGFBP-3 mRNA expression, but no differences were detected in IGFBP-3 or IGFBP-4 protein abundance in the ULF. This was attributed to the large among-cow variation and because IGFBP may be reduced due to prolonged progesterone exposure. Pershing et al. (2003) reported substantial amounts of IGFBP in the ULF of lactating dairy cows on $d 3$, but not on $d 7$ of a synchronized estrus. Lee et al. (1998) suggested that the loss of IGFBP during diestrus was likely a result of luminal proteolytic cleavage rather than decreased endometrial gene expression of IGFBP. Also, because in this study IGFBP-3 and IGFBP-4 were positively correlated with each other and IGFBP-4 was negatively correlated with plasma progesterone, one may infer that with increasing concentration of progesterone there is a subsequent decrease in IGFBP in the ULF. Lack of a correlation between concentations of plasma IGF-I and ULF content of IGF-I at d17 of pregnancy may reflect prior local utilization of IGF-I by the developing conceptus.

The observed effects of consuming FO on endometrial responses suggest that the uterus does indeed respond to the EPA and DHA fatty acids as candidate ligands 
that regulate gene expression. Feeding FO increased the amount of EPA and DHA in the endometrium, liver, and mammary tissue, and DHA was increased in the milk fat compared with control-fed cows (Bilby et al., 2006b). Thus, these ligands are available to target tissues once absorbed from the digestive tract.

\section{CONCLUSIONS}

High-producing dairy cows at first service during early lactation seem to have suboptimal plasma concentations of IGF-I, which is a potent stimulator of embryo and conceptus growth. Treatment with bST increased plasma IGF-I concentrations to possibly an optimal concentration that tended to increase pregnancy rate associated with an increase in conceptus length and enhanced production of the antiluteolysin IFN- $\tau$. Treatment with bST caused a costimulation in steadystate concentrations of endometrial IGF-II mRNA that may ultimately support continued development of the conceptus and prepare the endometrium for implantation and placentation. Delivery of supplemental unsaturated fatty acids to the lower gut for absorption may target reproductive tissues to regulate reproductive function and fertility. Not only did feeding calcium salts of FO increase milk production, but also altered gene expression of IGF-I and IGF-II in the endometrium and metabolic hormones (insulin, GH, and IGF-I) in a manner that may be beneficial to pregnancy. Interactions between a pharmaceutical (i.e., bST) and a nutraceutical (i.e., FO) in which differential bST responses were observed in the uterus and the peripheral system warrant further investigation. Such nutraceutical and pharmaceutical approaches, as demonstrated in the present study, provide new alternatives for development of nutritional-reproductive management programs to improve reproductive efficiency.

\section{ACKNOWLEDGMENTS}

Authors thank the staff of the University of Florida Dairy Research Unit for assistance in feeding and managing the experimental cows. Authors also express appreciation to Larry Eubanks and the staff of the University of Florida Meats Laboratory for timely and careful sacrifice of experimental cows. Authors also thank Select Sires for the donation of the semen, Pharmacia Animal Health for donation of Lutalyse, Intervet Inc. for donation of Fertagyl, and Virtus Nutrition for donation of EnerG II Reproduction formula for this experiment. This journal article was supported by the Florida Agricultural Experiment Station. Financial support also was received by the NRI Competitive Grant Program-USDA, grant no. 98-35203-6367.

\section{REFERENCES}

Badinga, L., R. J. Collier, W. W. Thatcher, C. J. Wilcox, H. H. Head, and F. W. Bazer. 1991. Ontogeny of hepatic bovine growth hormone receptors in cattle. J. Anim. Sci. 69:1925-1934.

Bauman, D. E., R. W. Everett, W. H. Weiland, and R. J. Collier. 1999. Production responses to bovine somatotropin in northeast dairy herds. J. Dairy Sci. 82:2564-2573.

Bilby, C. R., J. F. Bader, B. E. Salfen, R. S. Youngquist, C. N. Murphy, H. A. Garverick, B. A. Crooker, and M. C. Lucy. 1999. Plasma GH, IGF-I, and conception rate in cattle treated with low doses of recombinant bovine GH. Theriogenology 51:1285-1296.

Bilby, T. R., A. Guzeloglu, S. Kamimura, S. M. Pancarci, F. Michel, H. H. Head, and W. W. Thatcher. 2004. Pregnancy and bovine somatotropin in nonlactating dairy cows: Ovarian, conceptus, and insulin-like growth factor system responses. J. Dairy Sci. 87:3256-3267.

Bilby, T. R., A. Guzeloglu, L. A. MacLaren, C. R. Staples, and W. W. Thatcher. 2006a. Pregnancy, bovine somatotropin and dietary n3 fatty acids in lactating dairy cows: II. Endometrial gene expression related to maintenance of pregnancy. J. Dairy Sci. 89:3375-3385.

Bilby, T. R., T. Jenkins, C. R. Staples, and W. W. Thatcher. 2006b. Pregnancy, bovine somatotropin and dietary n-3 fatty acids in lactating dairy cows: III. Fatty acid distribution. J. Dairy Sci. 89:3386-3399.

Choi, B. R., and D. L. Palmquist. 1996. High fat diets increase plasma cholecystokinin and pancreatic polypeptide, and decrease plasma insulin and feed intake in lactating cows. J. Nutr. 126:2913-2919.

Garbarino, E. J., J. A. Hernandez, J. K. Shearer, C. A. Risco, and W. W. Thatcher. 2004. Effect of lameness on ovarian activity in postpartum Holstein cows. J. Dairy Sci. 87:4123-4131.

Geisert, R. D., C.-Y. Lee, F. A. Simmen, T. Zavy, A. E. Fliss, F. W. Bazer, and R. C. M. Simmen. 1991. Expression of messenger RNAs encoding insulin-like growth factor-I, -II, and insulin-like gowth factor binding Protein-2 in bovine endometrium during the estrous cycle and early pregnancy. Biol. Reprod. 45:975-983.

Khan, A. S., and J. P. Vanden Heuvel. 2003. Role of nuclear receptors in the regulation of gene expression by dietary fatty acids. J. Nut. Biochem. 14:554-567.

Kirby, C. J., M. F. Smith, D. H. Keisler, and M. C. Lucy. 1997. Follicular function in lactating dairy cows treated with sustained release bovine somatotropin. J. Dairy Sci. 80:273-285.

Lee, C. Y., M. L. Green, R. C. M. Simmen, and F. A. Simmen. 1998. Proteolysis of insulin-like growth factor-binding proteins (IGFBPs) within the pig uterine lumen associated with peri-implantation conceptus development. J. Reprod. Fertil. 112:369377.

Littell, R. C., G. A. Milliken, W. W. Stroup, and R. D. Wolfinger. SAS for Mixed Models. 1996. SAS Institute Inc., Cary, NC.

Mattos, R., A. Guzeloglu, L. Badinga, C. R. Staples, and W. W. Thatcher. 2003. Polyunsaturated fatty acids and bovine interferon- $\tau$ modify phorbol ester-induced secretion of prostaglandin $\mathrm{F}_{2 \alpha}$ and expression of prostaglandin endoperoxide synthase- 2 and phospholipase-A2 in bovine endometrial cells. Biol. Reprod. 69:780-787.

Mattos, R., C. R. Staples, and W. W. Thatcher. 2000. Effects of dietary fatty acids on reproduction in ruminants. Rev. Reprod. 5:38-45.

Moreira, F., L. Badinga, C. Burnley, and W. W. Thatcher. 2002a. Bovine somatotropin increases embryonic development in superovulated cows and improves post-transfer pregnancy rates when given to lactating recipient cows. Theriogenology 57:1371-1387.

Moreira, F., C. Orlandi, C. A. Risco, R. Mattos, F. Lopes, and W. W. Thatcher. 2001. Effects of presynchronization and bovine somatotropin on pregnancy rates to a timed artificial insemination protocol in lactating dairy cows. J. Dairy Sci. 84:1646-1659.

Moreira, F., F. F. Paula-Lopes, P. J. Hansen, L. Badinga, and W. W. Thatcher. 2002b. Effects of growth hormone and insulin-like growth factor-I on development of in vitro derived bovine embryos. Theriogenology 57:895-907.

Pershing, R. A., A. C. Dinges, W. W. Thatcher, and L. Badinga. 2003. Plasma and uterine insulin-like growth factor-I (IGF-I) and IGF- 
binding proteins in lactating dairy cows treated with bovine somatotropin. J. Anim. Vet. Adv. 2:67-73.

Pershing, R. A., M. C. Lucy, W. W. Thatcher, and L. Badinga. 2002. Effects of bST on oviductal and uterine genes encoding components of the IGF system in lactating dairy cows. J. Dairy Sci. 85:3260-3267.

Rorie, R. W., C. F. Rosenkrans, and A. J. Aishman. 2004. Effects of bovine somatotropin treatment on A.I. pregnancy rate in dairy heifers. Reprod. Fertil. Dev. 16:132. (Abstr.)

Sangsritavong, S., D. K. Combs, R. Sartori, L. E. Armentano, and M. C. Wiltbank. 2002. High feed intake increases liver blood flow and metabolishm of progesterone and estradiol-17beta in dairy cattle. J. Dairy Sci. 85:2831-2842.

Santos, J. E. P., S. O. Juchem, R. L. A. Cerri, K. N. Galväo, R. C. Chebel, W. W. Thatcher, C. S. Dei, and C. R. Bilby. 2004. Effect of bST and reproductive management on reproductive performance of Holstein dairy cows. J. Dairy Sci. 87:868-881.

Spencer, T. E., A. G. Stagg, T. L. Ott, G. A. Johnson, W. S. Ramsey, and F. W. Bazer. 1999. Differential effects of intrauterine and subcutaneous administration of recombinant ovine interferon tau on the endometrium of cyclic ewes. Biol. Reprod. 61:464-470.
Spicer, L. J., E. Alpizar, and S. E. Ecternkamp. 1993. Effects of insulin, insulin-like growth factor I, and gonadotropins on bovine granulosa cell proliferation, progesterone production, estradiol production, and (or) insulin-like growth factor I production in vitro. J. Anim. Sci. 71:1232-1241.

Staples, C. R., J. M. Burke, and W. W. Thatcher. 1998. Influence of supplemental fats on reproductive tissues and performance of lactating cows. J. Dairy Sci. 81:856-871.

Thatcher, W. W., A. Guzeloglu, R. Mattos, M. Binelli, T. R. Hansen, and J. K. Pru. 2001. Uterine-conceptus interactions and reproductive failure in cattle. Theriogenology 56:1435-1450.

Wilcox, C. J., W. W. Thatcher, and F. G. Martin. 1990. Statistical analysis of repeated measurements in physiological experiments. Pages 141-145 in Proc. Final Research Co-ordination Meeting of the FAO/IAEA/ARACAL III Regional Network for Improving the Reproductive Management of Meat- and Milk-Producing Livestock in Latin America with the Aid of Radioimmunoassay. International Atomic Energy Agency, Vienna, Austria.

Wildman, E. E., G. M. Jones, P. E. Wagner, H. F. Troutt, and T. N. Lesch. 1982. A dairy cow body condition scoring system and its relationship to selected production characteristics. J. Dairy Sci. $65: 495-501$ 